\title{
BIM Digital Platform for First Aid: Firefighters, Police, Red Cross
}

\author{
Alberto Pavan, Cecilia Bolognesi, Franco Guzzetti, Elisa Sattanino, \\ Elisa Pozzoli, Lara D’Abrosio, Claudio Mirarchi and Mauro Mancini
}

\begin{abstract}
This document explains the use of BIM in emergency response scenarios, considering both the current rescue procedures and the innovative development of a digital platform able to support first aid, firefighters, civil protection, police, traffic wardens, etc. This ongoing study has a practical aim: to allow all rescuers to intervene promptly and safely in places where there are alarm conditions. Thanks to the BIM methodology, linked to indoor navigation of the building and Google Maps tools, in case of an intervention users will be able to query a digital model for information. Starting from these premises, this paper assumes and analyses the methodology and tools used to develop the project of a BIM digital platform for first aid.
\end{abstract}

Keywords BIM digital platform $\cdot$ First aid $\cdot$ Indoor navigation of buildings $\cdot$ IFC parameters

\section{Introduction}

Despite the wide range of occupations, professional rescuers share a unique responsibility: saving lives. This type of work implies a continuous training of the staff, and a continuous update of the techniques and tools to be adopted in order to face different scenarios. The efficiency of a building rescue operation is often slowed down by the timing of receiving data in real time, concerning traffic congestion, the state of an ongoing construction site or the presence of some unexpected event. For instance, in the case of a fire, a main role is played by the firefighting team because they

\footnotetext{
A. Pavan · C. Bolognesi · F. Guzzetti · E. Sattanino ( $\varangle) \cdot$ L. D’Abrosio · C. Mirarchi

Architecture, Built Environment and Construction Engineering-ABC Department, Politecnico di Milano, Milan, Italy

e-mail: elisa.sattanino@polimi.it

M. Mancini

Department of Management, Economics and Industrial Engineering_-DIG, Politecnico di Milano, Milan, Italy

E. Pozzoli

Milan, Italy

(C) The Author(s) 2020

B. Daniotti et al. (eds.), Digital Transformation of the Design, Construction and Management Processes of the Built Environment, Research for Development, https://doi.org/10.1007/978-3-030-33570-0_25
} 
have to collect all the main information about the building while scouting the site. In the majority of cases, the knowledge of the how a building is planned out or, for instance, the placement of lifts, safety exits or specific rooms are difficult to source in real time. Currently there are no platforms suitable on the market to help rescue services, including ambulances technicians, firefighters, police officers, to identify the most suitable path for their destination, allowing in the same application for the chance to visualise the useful information of a building for emergency operators, navigating a $3 \mathrm{~d}$ model in real time. In this scenario the Italian emergency sector is becoming aware of the numerous advantages of the BIM (Building Information Modelling) method linked to Indoor Navigation and to GIS (Geographic Information System). ${ }^{1}$

The indoor navigation approach to public buildings is a developing reality that offers a considerable potential, not only in the retail sector, but also in emergency situations, increasing people's safety. On the other hand, the GIS tools plays a fundamental role in the analysis of an area, providing information such as the size of a street, the height of a viaduct, the presence of crowded public spaces and so on.

In this paradigm, the Politecnico di Milano recognises the importance of realizing a Digital Platform, where BIM and GIS coexist, in order to provide a mobile app (for tablet, smartphone or $3 \mathrm{~d}$ visualizers) that helps rescuers.

\section{3D BIM Project}

Financed by Regione Lombardia, the 3D BIM project is part of the "Smart Living" context ${ }^{2}$ and sees the partnership of the Politecnico di Milano with the two Italian companies Noovle spa and Fasternet spa.

The 3D BIM Project aims to create an innovative system for storing and displaying geographic information of an area and its buildings (public and private), such as to allow rescuers (First Aid, Fire Brigade, Police, City Patrol, etc.) the chance to intervene promptly and safely. The objective of the project is the realization of a cloud platform that will allow the professionals (architects) to insert a simplified and georeferenced survey of the buildings. The platform will give users the chance to store BIM models, initially modelled with an Authoring software, enriching them with all the information deemed fundamental by the safety and rescue organs to act promptly in case of an emergency.

\footnotetext{
${ }^{1}$ The GIS (Geographical Information System) is a geographic information system thanks to which it is possible to create maps, extract data, visualize scenarios three-dimensionally, look into specific elements and extrapolate geometries with data. The contribution of the GIS in this area is relevant because there is a large amount of information related to the geometries of objects.

${ }^{2}(. .$.$) The "Smart Living" call is aimed at supporting development and innovation projects car-$ ried out by partnerships of companies in the construction, wood, home furnishing, household and High-tech sectors in collaboration with the university system, finalizing the introduction of new or improved products, processes/services from a technological, productive and organisational point of view, in order to enhance the theme of "intelligent Living.(...)" (Regione Lombardia).
} 


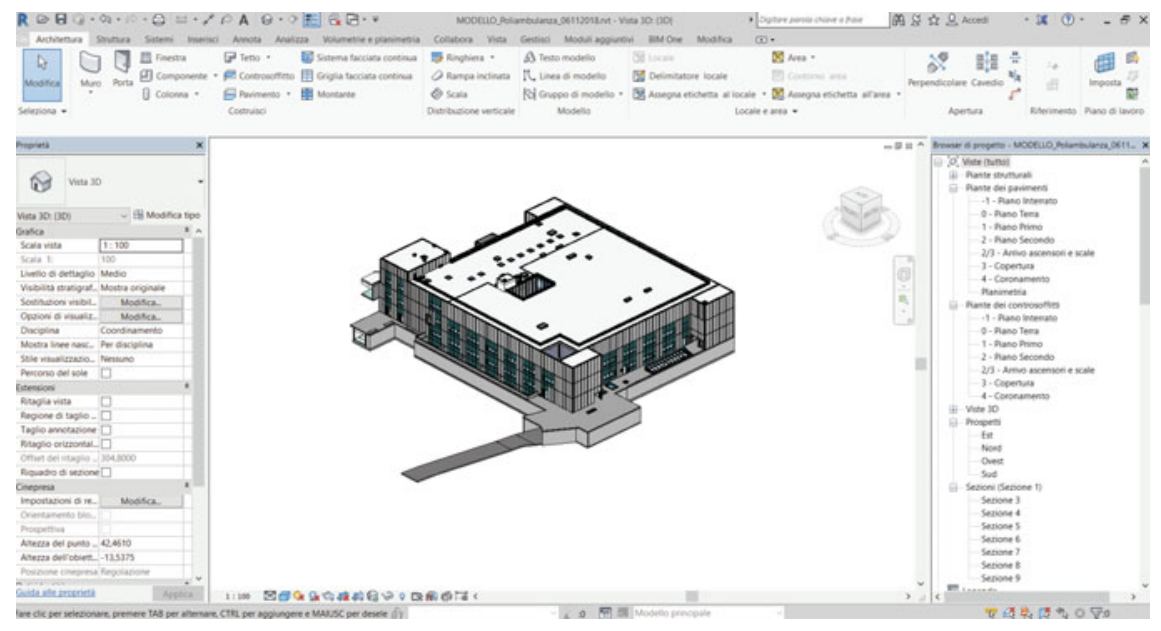

Fig. 1 3D model of the Poliambulanza Pavilion. Made with Revit (2018)

The main features of the platform are summarised as follows: a web portal for loading and managing BIM 3D models and its informative set; mobile application/tablet; search map of the building where users can view useful information; calculation of the shortest route to reach a particular building; display of the BIM model of the building and its information; indoor location of operator position and that of users.

In order to be able to test the functionalities of the research platform, in the analysis and development phase, the new hospital Pavilion of the Poliambulanza hospital of Brescia was modelled through BIM Authoring software (Fig. 1). The hospital did not have, even if recent, a BIM-oriented modelling design, so it has been analysed in all its components, from the georeferencing of the building in a GIS environment, to the geometric information up to the definition of the information attributes in view of $3 \mathrm{~d}$ modelling.

\section{Method}

The development of the project is articulated in three main phases:

- The first phase concerns the analysis and aims to interview the end users of the platform, identifying the technologies to be used for the development of the platform;

- The second phase concerns the implementation of all the requirements collected during the previous phase, realizing the $3 \mathrm{~d}$ model of the case study and the platform itself;

- In the final phase the tests are carried out. 


\subsection{Interviews and Questionnaires}

In the initial phase, it was necessary to perform preliminary interviews with the subjects mentioned above: the heads of the Red Cross of Milan (Lombardy's Regional committee), Milan's section of Firefighters and the State Police of Milan and Brescia were interviewed. Based on the information gathered in these meetings, we structured questionnaires to obtain useful information for the realization of the technical data sheets (Fig. 2).

In order to facilitate the subjects involved in the comprehension of the indicated requests, we prepared a number of examples of graphic representations and visualizations of the symbols, colours and annotations of architectural objects. Representation of doors, elevators and rooms for firefighters and the Red Cross were chosen in order to make the visualization of the elements in the platform as intuitive as possible. We decided to give the following indications:

- element accessible and recommended along the path: the architectural element, for example a door, is highlighted green and graphic symbols are displayed with the most important information (opening, REI, fitted with alarm, emergency exit,...);

- inaccessible element: model elements that are inaccessible, such as ports, are displayed in red with the symbol of the access ban;

\section{CONOSCERE L' EDIFICIO DALLINTERNO}

\section{5- Quali sono le informazioni tecniche che il soccorritore, una volta} entrato nell'edificio, deve conoscere in tempo reale? Cliccare tutte le opzioni ritenute utili per ciascun elemento indicato nell'apposita riga
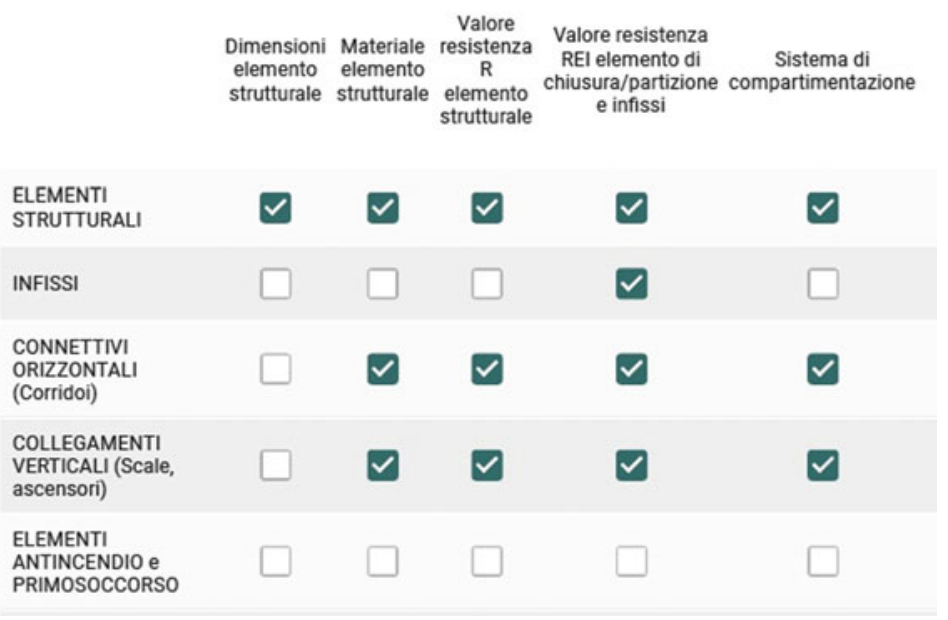

Fig. 2 Example from the survey for the Firefighters 


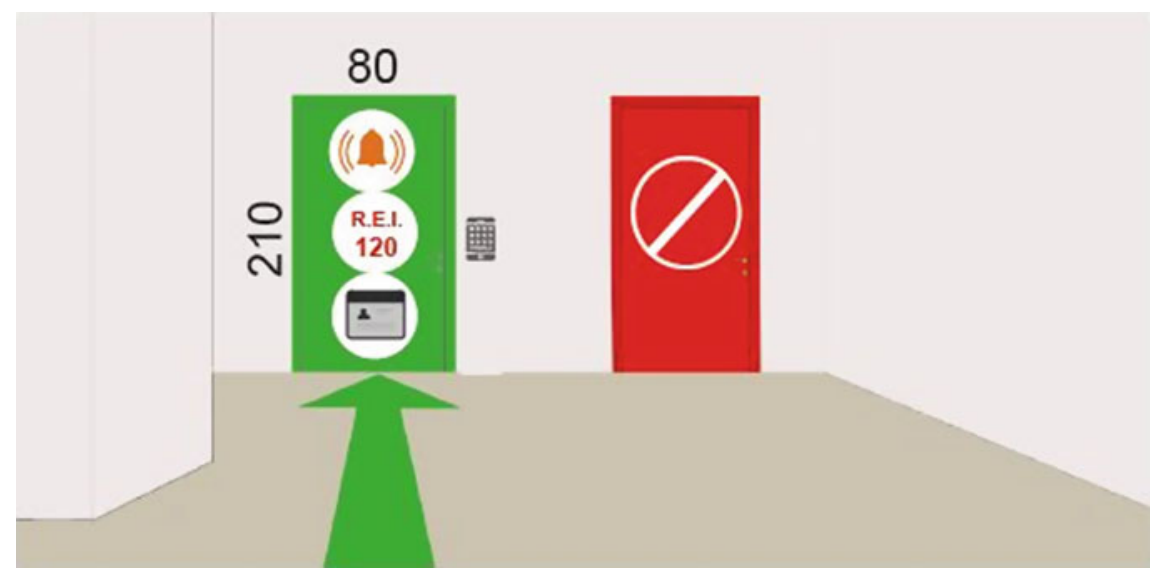

Fig. 3 Example of doors representation with the information for the rescuer

- elements in the model: all the elements (of a category) present in the model that the user wants to see are coloured yellow.

The route to follow is indicated in green with an arrow, allowing the operator/rescuer to arrive at their destination in the shortest possible time, along the most suitable and safe path (Fig. 3).

Following the representation of the objects, a visualization of the paths for the end users was defined. We received questionnaire replies from the firefighters and the Red Cross surveys.

\subsection{Structuring Technical Data Sheets and BIM Object Management}

Starting from the definition of the recurring project scenarios in the modelling and management of BIM models by the design studios (Osello 2015), the informative attributes of the buildings useful for the development of the platform were defined. ${ }^{3}$

With the aim of providing a complete mapping of the information that is considered fundamental to identify a building and its components, an Excel table was structured with attributes, ${ }^{4}$ following these macro-areas: territory, building, real estate

\footnotetext{
${ }^{3}$ Common scenarios concerning BIM design are defined as follows. Scenario 1: The object to be inserted in the 3D is modeled directly by an architect/engineer. 2: The object to be inserted in the model is downloaded from online object libraries (example Bimobject) and will be adapted to the needs of the designer. Choosing the most recurrent type of modelling, namely the one that includes objects created ad hoc by specialists in the sector and those downloaded from Internet sites, we have proceeded to define the information attributes tab of a generic building.

${ }^{4}$ An informational attribute is standardly defined as "any property of an area, a work or its physical entity (subject, object) or procedure (action), of a geometric or non-geometric nature. Informative
} 


\begin{tabular}{|c|c|c|c|c|c|}
\hline & \multicolumn{5}{|c|}{ FAMIGLIE DI ATTRIBUTI INFORMATIVI NON GRAFICI } \\
\hline $\begin{array}{l}\text { OBIETTIVO/ } \\
\text { USO }\end{array}$ & CATEGORIA & NORMA & PRESTAZIONE & GRAND. FISICA & OPERATORE \\
\hline ARCHITETTURA & Edificio & & & & $\begin{array}{l}\text { Progettista } \\
\text { architettonico }\end{array}$ \\
\hline STRUTTURE & Edificio & $\begin{array}{l}\text { Inquadramento normativo (DM } \\
\text { 16/01/1996) }\end{array}$ & & & $\begin{array}{l}\text { Progettista } \\
\text { struttutre }\end{array}$ \\
\hline ANTINCENDIO & Edificio & $\begin{array}{l}\text { Inquadramento normativo (D.M. } 246 \text { del } \\
\text { 1987) }\end{array}$ & Categoria & Altezza antincendio & \\
\hline $\begin{array}{l}\text { BARRIERE } \\
\text { ARCHITETTONICHE }\end{array}$ & Edificio & & & & \\
\hline SICUREZZA & Edificio & & & & $\begin{array}{l}\text { Coordinatore } \\
\text { della sicurezza } \\
\text { in fase di } \\
\text { esecuzione }\end{array}$ \\
\hline SITO OPERA-edificio & AFO-collegar & SPAZIO-locali & SISTEMA-impiant & SISTEMA-muri e solai & SUBSISTEMA-serrar \\
\hline
\end{tabular}

Fig. 4 Example of a technical table of a building, in line with UNI11337-1:2017

units, premises, connections, structures, plants, walls and ceilings, windows and doors. In the final analysis, the classes corresponding to the technical data sheets of the previous Excel table were defined according to the regulation UNI 11337-1:2017, as follows: Site, OPERA-building, AFO-links, ASO-real estate unit, SPACE-premises, system-structures, system-systems, subsystem-windows and doors (Fig. 4).

Following the structuring of the technical data sheets, they were processed with the IFC $^{5}$ study (ISO 16739; buildingSMART; Autodesk IFC standard manual) to define the most suitable export method of the case study modelled in Revit.

At an early stage, taking as a reference point the IFC scheme (ISO 16739:2013), the composition of the elements and their cataloging according to the ABS Building Element was analysed. On the basis of the classification given, a table of building elements was formulated, including beams, columns, continuous façades, doors, components, foundations, parapets, access ramps, rooves, floors, staircases, walls, windows, to which the respective IFC, attributes and reference Psets were associated. ${ }^{6}$ The model export tests were then performed both in the standard IFC $2 \times 3$ Coordination View format and with different information display settings (Table 1).

property of a territorial class (or superclass) or of the construction sector, of a model, of a constituent digital object or of a composition". (UNI 11337-1:2017).

${ }^{5}$ The Industry Foundation Classes (IFC) is an open and standardized data format useful for sharing model-related information, including different modeling software. Specifically, it consists of a complex structure of data, grouped according to a system of classification of the physical components of a building (walls, doors, floors etc.), their attributes (volume, quantity, transmittance etc.) and the relations between them. Without this framework there can be no sharing of building information.

${ }^{6}$ The classes identified are valid for all models and are defined as: rooms, walls, continuous façade, doors, stairs, floors, rooves, countertops, columns, beams, railings, walls, ramps, fire alarm devices, fire extinguishers, safety devices, special equipment (lifts, elevators, hoists, etc.), mechanical equipment, electrical appliances, electrical equipment, windows. 
Table 1 Extract of the table concerning the different IFC exportations with Revit

\begin{tabular}{|c|c|c|}
\hline Export Revit setup & $\begin{array}{l}\text { Class of visible attributes IFC } \\
\text { (wall) }\end{array}$ & $\begin{array}{l}\text { Class of visible attributes IFC } \\
\text { (door) }\end{array}$ \\
\hline $\begin{array}{l}\text { Export IFC common property } \\
\text { sets }\end{array}$ & $\begin{array}{l}\text { Identification, Location, } \\
\text { Quantities, Material, Profile, } \\
\text { Relations, Classification, } \\
\text { Hyperlinks, } \\
\text { Pset_WallCommon }\end{array}$ & $\begin{array}{l}\text { Identification, Location, } \\
\text { Quantities, Material, } \\
\text { Relations, Classification, } \\
\text { Hyperlinks, IfcDimensions, } \\
\text { IfcDoorPanelProperties, } \\
\text { Pset_Door Common }\end{array}$ \\
\hline $\begin{array}{l}\text { Export IFC common property } \\
\text { sets, export Revit property } \\
\text { sets }\end{array}$ & $\begin{array}{l}\text { Identification, Location, } \\
\text { Quantities, Material, Profile, } \\
\text { Relations, Classification, } \\
\text { Hyperlinks, Other, Building, } \\
\text { ID Data, Size, Phases, } \\
\text { Graphics, Analytical } \\
\text { Properties, Pset_Wall } \\
\text { Common, Structural, } \\
\text { Restrictions }\end{array}$ & $\begin{array}{l}\text { Identification, Location, } \\
\text { Quantities, Material, Profile, } \\
\text { Relations, Classification, } \\
\text { Hyperlinks, Other, } \\
\text { Other(Type), Building } \\
\text { (Type), ID Data, ID } \\
\text { Data(Type), Size, Size } \\
\text { (Type), Phases, } \\
\text { IfcDimensions, } \\
\text { IfcDoorPanelProperties, } \\
\text { Materials and finishing } \\
\text { (Type), Analytical Properties } \\
\text { (Type), Pset_Door Common, } \\
\text { Restrictions }\end{array}$ \\
\hline $\begin{array}{l}\text { Export IFC common property } \\
\text { sets, export Revit property } \\
\text { set, export schedules as Pset }\end{array}$ & $\begin{array}{l}\text { Identification, Location, } \\
\text { Quantities, Material, Profile, } \\
\text { Relations, Classification, } \\
\text { Hyperlinks, Other. Base } \\
\text { Quantities, Building, ID } \\
\text { Data, Size, Phases, Graphics, } \\
\text { Analytical Properties, } \\
\text { Pset_Wall Common, } \\
\text { Structural, Restrictions }\end{array}$ & $\begin{array}{l}\text { Identification, Location, } \\
\text { Quantities, Material, Profile, } \\
\text { Relations, Classification, } \\
\text { Hyperlinks, Other, Other } \\
\text { (Type), Base Quantities, } \\
\text { Building (Type), ID Data, ID } \\
\text { Data (Type), Size, Size } \\
\text { (Type), Phases, Ifc } \\
\text { Dimensions, Ifc } \\
\text { DoorPanelProperties, } \\
\text { Materials and finishing } \\
\text { (Type), Analytical properties } \\
\text { (Type), Pset_Door Common, } \\
\text { Restrictions }\end{array}$ \\
\hline
\end{tabular}

The IFC files obtained from the Solibri viewers, BIM Model Viewer and usBIM. Viewer + V. 7.00 and (Acca Software) were imported to verify the management and loss of data. Based on the needs of respondents and the information visible in the IFC viewers, an Excel table was defined with the attributes to be shown in the platform and those to be hidden. For each attribute, users (VVF, CRI, Police) have been defined to display the information on the platform (Fig. 5). 


\begin{tabular}{|c|l|l|}
\hline UTENTE & \multicolumn{1}{|c|}{ ATTRIBUTI da aggiungere ex-novo } & VALORE \\
\hline WVF, Polizia,CRI & Porta allarmata & YESNO \\
\cline { 2 - 2 } WV, Polizia,CRI & Chiusura porta con badg & YESNO \\
\cline { 2 - 3 } WF, Polizia,CRI & Chiusura porta con codice & YESNO \\
\cline { 2 - 3 } WV & Altezza netta & NUMBER \\
WVF & Tempo di chiusura porta & NUMBER \\
\cline { 2 - 3 } WF, CRI & Larghezza netta & \\
\hline
\end{tabular}

Fig. 5 Extract from the excel table. Attributes and users

\subsection{Geographic Information System (GIS) Use in the Project}

The topographical database, basis of the Webgis of the province of Brescia, has been used for two different phases of the work: on the one hand to provide the coordinates for the correct positioning of the model with respect to the system of Reference, on the other to derive all useful information relating to points of interest within the city or otherwise intersecting the path identified and viewable by the rescue organs. The topographical DB standard is strictly recognized on a regional and national level. This study then focused on considering, deriving from the DBT, a likely recovery (and thus replicable) model for a regional and national level. Starting from the DBT of Brescia, in a first phase, the shape of the buildings' points of interest and shape of the road were selected.

Within each category data was selected, where present, which provides useful information for knowing the influx of people in given moments of the day. This part of the analysis was also realized with the help of Google Maps which allows users to visualize inside information about the opening and closing times of the activities.

The shapes thus recovered will be positioned and highlighted within the interactive map of the application, while the shapes relating to road traffic will be used for the possibility of identifying closed roads and dead ends by setting a selection considering at the geometric level the segments that are open.

\section{Results}

The goal of this research project is the creation of a graphic database and an information database, poured into a cloud platform where the different users can view, through a web and mobile interface (on tablets/smartphones or 3D viewers), the information coming from the BIM models (Mirarchi et al. 2018) overlapped by specific information for assistance. The approach of modelling for the rescuers' path will then take place with traces on the road graph already enriched with information from Google the database, which will allow users to reach the building. The travel tracking is done by GPS connected to the smart tool in the hands of the rescuer. Inside 
the building, it will be carried out using Beacon ${ }^{7}$ technology, capable of locating the user with precision in the exact spatial location within the building itself and thus in the model. The research will soon reach its conclusion with the testing of the platform that Noovle s.p.a. is developing and with the final approval of the users.

Below is a high-level description of the components used for the developing platform:

- Frontend: this component will be responsible for processing all requests from the desktop and mobile clients and for communicating with the upload component when creating the information.

- Upload: it has the task of processing the IFC file format in order to extrapolate the most relevant information and to prepare it to be processed by the BIM Service.

- Database: This is a classic relational database that can save geographic and nongeographic information that will be analysed later.

- Static Content: This platform component will contain all static information such as images, configuration files and static BIM models loaded into the platform.

- BIM Server: This has the task of processing the IFC BIM files in order to make them usable and viewable on all devices.

\section{Conclusion}

The research described traces a path starting from generic models of buildings (i.e. modelled by any BIM-oriented software) to outline them as navigational tools for the specific use of rescue services.

Thanks to geo-localization and three-dimensional modelling, although simplified, of the masses of buildings and their common parts (gardens, atriums, staircases, elevators, technical rooms, electric control units, roofs, etc.) the rescue services will have all the information needed to optimize their time of intervention.

With this system of mapping and geolocation of environments, the information will be able to reach them through any mobile device (smartphone) or even directly, in augmented reality, on portable viewers (digital glasses).

For public buildings a BIM modelling of greater detail and the use of Beacon sensors for georeferencing will guarantee the localization also in internal up to the single environment besides the possibility of using the same device regarding an individual civilian as a direct source of the information necessary to the rescuers.

\footnotetext{
${ }^{7}$ Bluetooth beacons are small radio transmitters that send signals in a radius of 10-30 $\mathrm{m}$ (interior spaces). The benefits of beacons are: that they are affordable (three to thirty euros), can be installed with minimal effort, you can determine a position with accuracy up to $1 \mathrm{~m}$ and are supported by many operating systems and devices. Beacons can be used for both client-based and server-based applications. The new standard BLE (Bluetooth Low Energy) is also very energy efficient, in fact the choice fell on BLE technology, which allowed us to achieve excellent tracking results by keeping extremely small, cheap (almost disposable) tags.
} 
In the first processes of Augmented Reality (realized by overlapping clear information for paths on the real environment) the emergence of information relating to the surrounding environment can be seen both through wearable devices and by smart devices in our case held by the rescue operator identified within the Beacon sensor network. After its trial the project of course will benefit from the possibility of spreading into several environments and on a large scale: starting from socio-health care to building large private properties.

\section{References}

AAVV (2013) Realtà Aumentate. Esperienze, strategie e contenuti per l'Augmented Reality. Apogeo Education, Milano

Autodesk (Nov 2018) Detailed instructions for handling IFC files. https://abcdblog.typepad.com/ abcd/2018/Success_Stories/IFC-Manual-2018-ENU.PDF

Battini C (2017) Realtà virtuale, aumentata e immersiva per la rappresentazione del costruito. Altralinea, Firenze

Costin A, Pradhananga N, Teizer J (2014) Passive RFID and BIM for real-time visualization and location tracking. In: Proceedings of the construction research congress: construction in a global network, ASCE, Atlanta, GA, USA, p 169-178

Eastman C, Teicholz P, Sacks R, Liston K (2016) Il BIM: Guida completa al Building Information Modeling per committenti, architetti, ingegneri, gestori immobiliari e imprese. Hoepli, Milano

http://www.regione.lombardia.it/wps/portal/istituzionale/HP/DettaglioBando/servizi-e-inform azioni/imprese/filiere-eccellenti/smart-living/smart-living

https://www.buildingsmart.org/

https://sit.provincia.brescia.it/Metadati

Lee Y-C, Eastman C, Solihin W (2016) An ontology-based approach for developing data exchange requirements and model views of building information modelling. Adv Eng Inf 30(3):354-367

Mirarchi C, Pavan A, De Marco F (2018) Supporting facility management processes through endusers' integration and coordinated BIM-GIS technologies. Int J Geo Inf 7(5):191, 1-10

Osello A (2015) Building information modelling—geographic information system—augmented reality per il facility management. Dario Flaccovio Editore, Palermo

Pavan A, Mirarchi C, Giani M (2017) BIM: metodi e strumenti, Tecniche nuove

\section{Standards and Laws}

ISO 16739 Industry foundation classes (IFC) for data sharing in the construction and facility management industries-Part 1: Data schema

Level of development (LOD) specification (2019)

NBS BIM object standard

UNI 11337-1:2017 Edilizia e opere di ingegneria civile—Gestione digitale dei processi informativi delle costruzioni-Parte 1: Modelli, elaborati e oggetti informativi per prodotti e processi

UNI 11337-4:2017 Edilizia e opere di ingegneria civile-Gestione digitale dei processi informativi delle costruzioni-Parte 4: Evoluzione e sviluppo informativo dei modelli, elaborati e oggetti 
Open Access This chapter is licensed under the terms of the Creative Commons Attribution 4.0 International License (http://creativecommons.org/licenses/by/4.0/), which permits use, sharing, adaptation, distribution and reproduction in any medium or format, as long as you give appropriate credit to the original author(s) and the source, provide a link to the Creative Commons license and indicate if changes were made.

The images or other third party material in this chapter are included in the chapter's Creative Commons license, unless indicated otherwise in a credit line to the material. If material is not included in the chapter's Creative Commons license and your intended use is not permitted by statutory regulation or exceeds the permitted use, you will need to obtain permission directly from the copyright holder.

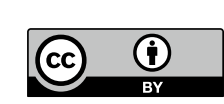

